$$
\begin{aligned}
& \text { جامعـة المنصــورة } \\
& \text { كليــة التربية }
\end{aligned}
$$

Enhancing Middle School Pupils' Motivation Toward Writing Through Edmodo Website

\author{
By \\ Hadeer Eihab
}

Superuisars

Dr. Rehab Abu- Alghait Gohar Prof. Dr. Aly Abdel-Samea Qoura

Journal of The Faculty of Education-Mansoura University No. 113 - Jan . 2021 


\title{
Enhancing Middle School Pupils' Motivation Toward Writing Through Edmodo Website
}

\section{Hadeer Eihab}

\begin{abstract}
The study aimed at investigating the impact of using Edmodo on enhancing motivation of the middle school pupils. To fulfill the purpose of the study, an instrument was constructed (a motivation scale). The instrument was administered before and after the experiment to measure the students' motivation toward writing. The validity and reliability of the study instrument were established before its use in the study. The quasi-experimental design had been adopted in the study. The participants of the study consisted of 28 pupils of eighth graders at Adwaa Alhedaya International Schools, in the kingdom of Saudi Arabia, where 14 pupils represented the experimental group and 14 represented the control group. Edmodo was implemented with the experimental group, whereas the control group received the regular teaching. Results of the study revealed that practicing EFL writing through Edmodo led to significant improvement in students motivation. Therefore, it was concluded that using Edmodo as a mean of communicating and practicing the English language was highly effective in improving the participants' performance.
\end{abstract}

Key words: motivation, Edmodo, Egypt.

\section{Introduction}

English has been gaining importance as the most used language in the world. Continuous growth of new technologies makes English even more essential for everyone to communicate efficiently. Thus more emphasis should be given to teaching writing in English as a writing skill that may function as an important gate leading students to a successful career in this information technology driven world Warschauer(2006)

Writing is a significant skill in language production. Its significance increases when it comes to writing in English language which is extensively used for global mediation of knowledge Rahman (2002). Hyland (2003)believes that performance in language development is subject to improvement in writing skills. "Writing is the transformation of the linguistic rules of language into usage" Widdowson(2001).Thus, students should be competent and selective when they intend to produce any written discourse which demands conscious intellectual effort from learners to write coherent and meaningful paragraphs. 
Students' writing ability can be improved by fostering their interest, motivation and enjoyment for writing, through technology Graham \&Perin ( 2007). Most importantly, it is necessary that attitudes towards writing and dealing with its issues are changed. Teachers must employ strategies to elicit ideas from students to be penned down on a piece of paper to promote their verbal ability. Moreover, instant and critical feedback needs to be given on their output, so that their confidence is elevated Haide(2012).

The increase of interest in the use of computer-mediated communication (CMC)into students learning and English Language Teaching(ELT)has become a crucial part of a $21^{\text {st }}$ century education. Virtual Learning Environment as a supplementary tool for motivating and empowering independent learning and innovative teaching is practicing to deliver coursework in higher education.

Among many available technological educational tools, Edmodo has recently become very popular, it is a private micro-blogging service available at www.edmodo.com which provides a free secure learning platform. In other words, it is a social media platform often described as a facebook for education Enriquez(2014). It looks similar to facebook, but is much more private and safer for a learning environment in terms of allowing only teachers to create and manage accounts, and only their students, who receive a group code and register in the group, can access and join the group Majid(2011). Via Edmodo, teachers can send out quizzes and assignments, give feedback, receive complete assignments, assign grades, store and share content, maintain a class calendar, conduct polls and send alerts to individual students or the entire class.

By using Edmodo as the extension of the face-to-face interaction, it is expected that students can improve their English proficiency in a provided length of time, since it will increase the contact hours among students and teachers and facilitate peer feedback among students, which may create a productive learning environment for them Dewi(2014). It arises from the idea that the focus of cognitive change of an individual is created the individual mindset after the intervention of this technology tool.

The Edmodo microblogging is used as learning strategy for teaching writing. In its implementation, Edmodo is used by student to get collaborative writing activity in which students doing a writing process like planning, drafting, editing, and publishing. The utilization of Edmodo in teaching foreign language writing is focused to meet the social strategy which is very important in learning a language. 
The present study tries to assess the benefit of Edmodo which employs the principles of the theory of social constructivism. Social constructivism is a sociological theory of knowledge according to which human development is socially situated and knowledge is constructed through interaction with others Lynch(2016). The main focus of this theory is on an individual's learning that takes place because of his or her interactions in a group. An example of the constructivism theory is Edmodo ;not only do the 'shape' of the software tools indicate certain things about the way online courses should work, but the activities and texts produced within the group as a whole will help shape how each person behaves within that group.

\section{Review of Literature}

\section{Motivation}

Motivation is demonstrated to be one of the main determinants of second language learning achievement. Motivation is an essential element of successful language acquisition and is a dynamic process subject to continuous flux Do"rnyei(2001).In addition, Gredler(2001) defines motivation as the attribute that "moves" us to do or not do something. It is the internal and external factors that stimulate desire and energy in people to be continually interested and committed to a job, role, subject, or to make an effort to achieve a goal Dornyei( 2001). Schweder and Wissick (2008)also state that motivation is a student's drive to participate in the learning process. Some students are intrinsically motivated to learn and others require extrinsic motivation.

Similarly, the study defined motivation as the impulsive factor that moves and encourages students to interact during the whole process of writing and to effectively produce a well prepared piece of writing.

Young (2008) examined the effect of using technology tools on grades level, motivation attitude and attendance of students in the public school classroom. The sample of this study consisted of teachers from the Kaiserslautern school district. Teacher/student technology surveys were also used. In addition, observation and questionnaires were used as tools of the study. Study findings revealed that the use of technology was motivating for the students and lead to high levels of scores regarding English language. Hrastinski (2008) investigated the effect of online classroom on improving learning English as a second language. The study was conducted on two groups. 19 students including males and females were integrated as sample of the study. Interviews and observation were used as tools to collect information. Results indicated the importance of online classroom for 
learners of English. Also, it was indicated that using asynchronous elearning and using media such as e-mail, discussion boards, and blogs are very important in case of discussing important issues.

Gencilter(2009) examined the effect of technology in EFL classroom. The study is based on a questionnaire which was prepared on purpose. The groups were selected among Akdeniz University Preparatory Classes in the academic year 2007-2008. The questionnaire was composed of 15 questions about motivation and technology use in EFL classrooms. The questionnaire was administered to a representative group and then an item analysis was done. Next, it was administered to 350 students. There were 15 questions about technology and how to use it as a means of motivation in the language classes. Most of the students using technology increase their motivation and they point out that the most important equipment is computer connected projector in the classrooms. In this research it was also found that foreign language learning seemed to be affected by different technological equipment such as computers, projectors, video, films, internet, e-learning and multi-media. Students' responses have showed that there is a great relation between language-learning motivational factors and using technology

Bakhtiarvand(2014) conducted a study to explore the Influence of Using Technology on Iranian EFL Students' Motivation. A group of 60 English students majoring in English translation were selected at random. They were studying English at Payam-e-Noor university of Andimeshk, Iran. This empirical study was based on a questionnaire which was developed by Binnur (2011). The questionnaire was composed of 15 questions about motivation and technology use in EFL classrooms. The questionnaire was distributed among the subjects and then an item analysis was done.The questionnaire whose reliability was already established by Binnur (2011) was administered to a representative group (60 students) of Iranian EFL students and then an item analysis was done. $86.7 \%$ of students believed that they are motivated to work more in their EFL classes if technology is used. Only $13.3 \%$ of the students disagreed with this. Based on the chi-square statistical analysis of the results.

In view of the above studies, technology has become an essential factor to motivate students. Edmodo not only stimulates, but also enhances and motivates students. Hariri and Bahansal (2015) report high percentages of interaction and encouragement of incidental learning through Edmodo. The integration of Edmodo renders the students' perceptions of writing 
more positive and stimulate their interest and enjoyment in writing as an activity.

\section{Edmodo}

Edmodo is an educational website that takes the ideas of a social network and refines them and makes it appropriate for a classroom. Edmodo is a social learning network and discussion platform where teachers and students can interact and collaborate online

Arroyo (2011) viewed Edmodo as an inspiring teaching tool for knowledge to be constructed. Edmodo is a private micro blogging service which provides a secure and free learning platform Haygood, Garner \& Johnson(2012). Sutinen (2013) showed that Edmodo might serve as a space to collaborate between students and teachers. Edmodo is a free and secure learning platform which is free of advertisements, games and other distractions used to provide a simple way for teachers to create and manage online classroom, and enable students to connect with teachers and other students anywhere and anytime Al-Khatiri( 2015).

Similarly, the researcher defined Edmodo as a private platform conducted by the teacher to improve the English language and the writing skill in particular. An effective platform which provides students with a lot of features to facilitate their writing process and enable them to collaborate with their peers.

Al-Kathiri(2014) conducted a research to investigate the prospects of integrating Edmodo into Saudi EFL female secondary school instruction. The research concentrates on students' perceptions and challenges regarding Edmodo use and its effect on their attitudes towards EFL learning. The 42 participants were divided into two groups. The experimental group received traditional teaching along with a six-week daily interaction via Edmodo. The control group received traditional teaching only. Findings of the posttreatment questionnaire show that students' perceptions towards Edmodo were highly positive and that although there were considerable challenges to its integration, it appeared to have excellent potential for generating more positive attitudes towards EFL learning

Candrasari(2015) conducted a study to improve the students' writing skill through Edmodo Website of tenth grade students of SMKNI Wonosegoro in academic year(2015-2016). The subjects of this study consisted of 32 students in the class of X Multimedia 2(TMM2). The method used in this study was Classroom Action Research (CAR). The writer used two cycles. Each cycle consisted of planning, action, observation 
and reflection. Each cycle consisted of two meetings, the data in this study collected through documentation, field notes, questionnaire, and test. The results of the study showed that there was significant improvement of students' writing skill. There is a significant difference between pre-test and post-test. In conclusion, Edmodo Website could improve students' writing skill.

Wael(2015) investigated the effectiveness of using Edmodo as a teaching and learning virtual class to the product writing approach on enhancing Palestinian seventh graders' English writing skills and their attitudes towards writing. To achieve this aim the researcher followed the experimental approach so she chose a random sample of 50 EFL female students studying at Al-Majda Wasella prep "B" Girls school in the Directorated Education -West Gaza. The participants were divided into two equivalent groups. The findings of the study revealed that there were statistically significant difference between the main scores attained by the experimental group and that attained by the control group in the post writing test in favor of the experimental group. This means that the participants attitudes towards English writing after the implementation of the Edmodo positively changed.

Studies mentioned above have given momentum to Edmodo as an effective way to the teaching and learning of the EFL writing skill. Recently, Edmodo has been proved as a motivating and inspiring tool to engage students in the classroom and in English classes in particular.

\section{The pilot study}

The researcher conducted a pilot study to assess $8^{\text {th }}$ grade pupil's motivation toward writing. A selected sample was taken from Al-Raed International Schools in the kingdom of Saudi Arabia to check the pupils' motivation toward writing. The sample included 30 female participants.

In order to assess the pupils motivation toward writing, the researcher used a 14 item Motivation Scale Candrasari(2015).Table (1) reports the pupils motivation results. 


\section{Table (1) Results of the pupils' motivation toward writing}

\begin{tabular}{|c|c|c|c|}
\hline Statement & Agree & Uncertain & Disagree \\
\hline $\begin{array}{l}\text { 1. It is important to me that I make an A on a } \\
\text { writing assignment. }\end{array}$ & $35 \%$ & $60 \%$ & $25 \%$ \\
\hline $\begin{array}{l}\text { 2. I enjoy writing assignments that challenge } \\
\text { me. }\end{array}$ & $20 \%$ & $50 \%$ & $30 \%$ \\
\hline $\begin{array}{l}\text { 3. I revise my writing before submitting an } \\
\text { assignment. }\end{array}$ & $40 \%$ & $10 \%$ & $50 \%$ \\
\hline $\begin{array}{l}\text { 4. I like to write even if my writing will not } \\
\text { be graded. }\end{array}$ & $20 \%$ & $10 \%$ & $70 \%$ \\
\hline 5. I enjoy writing research papers. & $10 \%$ & $30 \%$ & $60 \%$ \\
\hline $\begin{array}{l}\text { 6. I would like to have more opportunities to } \\
\text { write in classes. }\end{array}$ & $10 \%$ & $10 \%$ & $90 \%$ \\
\hline $\begin{array}{l}\text { 7. Being a good writer is important in getting } \\
\text { a good job. }\end{array}$ & $25 \%$ & $45 \%$ & $30 \%$ \\
\hline $\begin{array}{l}\text { 8. I practice writing in order to improve my } \\
\text { skills. }\end{array}$ & $15 \%$ & $25 \%$ & $60 \%$ \\
\hline $\begin{array}{l}\text { 9. I want the highest grade in the class on a } \\
\text { writing assignment. }\end{array}$ & $25 \%$ & $45 \%$ & $30 \%$ \\
\hline $\begin{array}{l}\text { 10. I would rather write an essay than answer } \\
\text { multiple-choice questions. }\end{array}$ & $15 \%$ & $15 \%$ & $70 \%$ \\
\hline $\begin{array}{l}\text { 11. I want others to recognize me as a good } \\
\text { writer. }\end{array}$ & $10 \%$ & $30 \%$ & $60 \%$ \\
\hline 12. Spelling is easy for me & $40 \%$ & $30 \%$ & $30 \%$ \\
\hline 13. Choosing the right word is easy for me & $40 \%$ & $30 \%$ & $30 \%$ \\
\hline 14. I am motivated to write in my classes. & $15 \%$ & $10 \%$ & $75 \%$ \\
\hline Total & $23 \%$ & $29 \%$ & $51 \%$ \\
\hline
\end{tabular}

Results of the motivation scale show that $8^{\text {th }}$ grade pupils' motivation towards writing needs to be enhanced since $51 \%$ showed low motivation

\section{Statement of the problem}

Based on the literature review, the pilot study, and the researcher experience as an English language teacher, it was apparently evident that the pupils are in need of motivation toward writing. Thus, the current study investigates the effect of Edmodo Website to improve motivation toward writing. 


\section{Questions of the study}

The questions were:

1) What are the features of Edmodo website used to enhance motivation toward writing for the eighth grade pupils of Al-Raed International school?

2) What is the effectiveness of using Edmodo website to enhance motivation toward writing for the eighth grade pupils of Al-Raed International school?

\section{Hypotheses}

The following hypotheses were tested:

1) There is a statistically significant difference between the mean score of the experimental and the control group on the post administration of the motivation scale towards writing skill in favor of the experimental group.

2) There is a statistically significant difference between the mean score of the experimental group pre- and post- application of the motivation scale in favor of the post application.

\section{Purpose}

The purpose of this study was to

Identify the effectiveness of using Edmodo to enhance motivation toward writing for the eighth grade pupils.

\section{Definitions of Terms}

\section{Motivation}

Motivation is the energetic factor that create a goal for learning and continuously help to realize this goal during the learning process and writing process in particular. Motivation is the impulsive factor that urges students to use Edmodo to write and express their own ideas.

\section{Edmodo}

Edmodo is a virtual learning environment which provides pupils with a flexible and appropriate atmosphere to interact, share, write, express, comment and learn.

\section{Method}

\section{Participants}

The participants are two $8^{\text {th }}$ grade classes from Al-Ra'ed International School in the kingdom of Saudi Arabia. One of the classes serves as an 
experimental group and receives Edmodo Website activities, and the other class serves as a control group and receives the traditional teaching method.

\section{Design}

The researcher will adopt a quasi-experimental research including two groups of the $8^{\text {th }}$ grade pupils. The following figure illustrates the experimental design of the study.

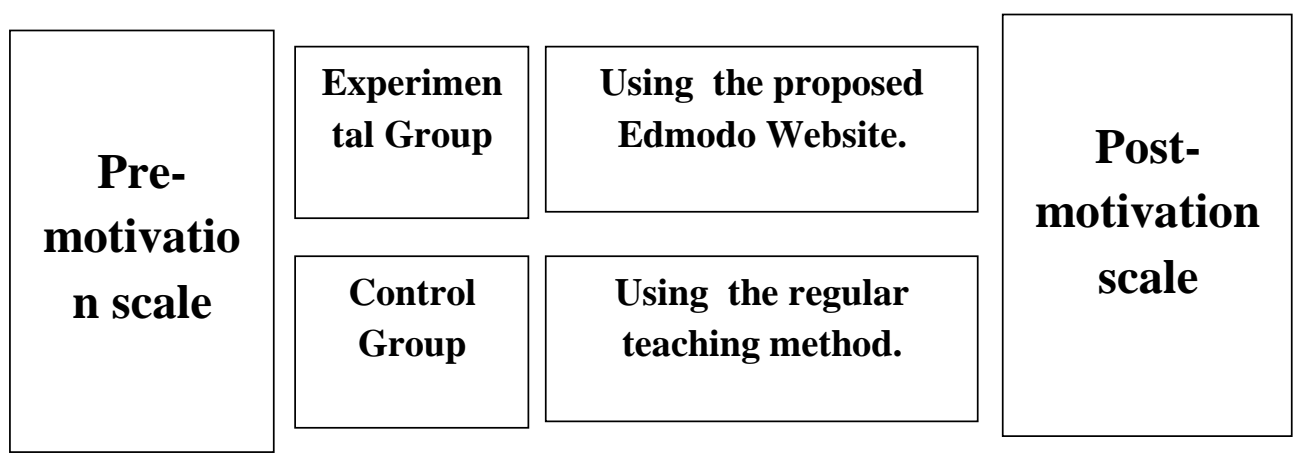

\section{Figure(1) Design of the study}

\section{Instruments}

A pre-post motivation scale will be designed to measure the pupils motivation toward writing.

\section{Results and Discussions}

The results of the study were statistically analyzed in terms of its hypotheses and they were discussed in the light of the theoretical background and related studies. Results of the study were reported as follows: 


\section{Table (2)}

Comparing the motivation level of the experimental and control groups in Post motivation scale

\begin{tabular}{|l|c|c|c|c|c|c|c|}
\hline \multicolumn{1}{|c|}{ Dimensions } & Group & $\mathbf{N}$ & $\begin{array}{c}\text { Mean } \\
\text { Rank }\end{array}$ & $\begin{array}{c}\text { Sum of } \\
\text { Ranks }\end{array}$ & $\mathbf{U}$ & $\mathbf{Z}$ & Sign \\
\hline $\begin{array}{l}\text { attitude toward } \\
\text { enjoying writing }\end{array}$ & Exp & 14 & 21.50 & 301.00 & 00 & 4.528 & 0.01 \\
\hline & Ctrl & 14 & 7.50 & 105.00 & & & \\
\hline $\begin{array}{l}\text { challenges while } \\
\text { writing }\end{array}$ & Exp & 14 & 7.50 & 105.00 & 00 & 4.513 & 0.01 \\
\cline { 2 - 9 } & Ctrl & 14 & 21.50 & 301.00 & & & \\
\hline \multirow{2}{*}{$\begin{array}{l}\text { The value of } \\
\text { writing }\end{array}$} & Exp & 14 & 21.50 & 301.00 & 00 & 4.526 & 0.01 \\
\hline & Ctrl & 14 & 7.50 & 105.00 & & & \\
\hline \multirow{2}{*}{ Total } & Exp & 14 & 20.57 & 288.00 & 13.0 & 3.916 & 0.01 \\
\cline { 2 - 9 } & Ctrl & 14 & 8.43 & 118.00 & & & \\
\hline
\end{tabular}

The results in the above table (2) indicate that there were so clear differences in the administration of the post motivation scale between the experimental and control group in favor of the experimental group which signifies the effective impact of Edmodo's features to enthusiastically encourage the pupils to write.

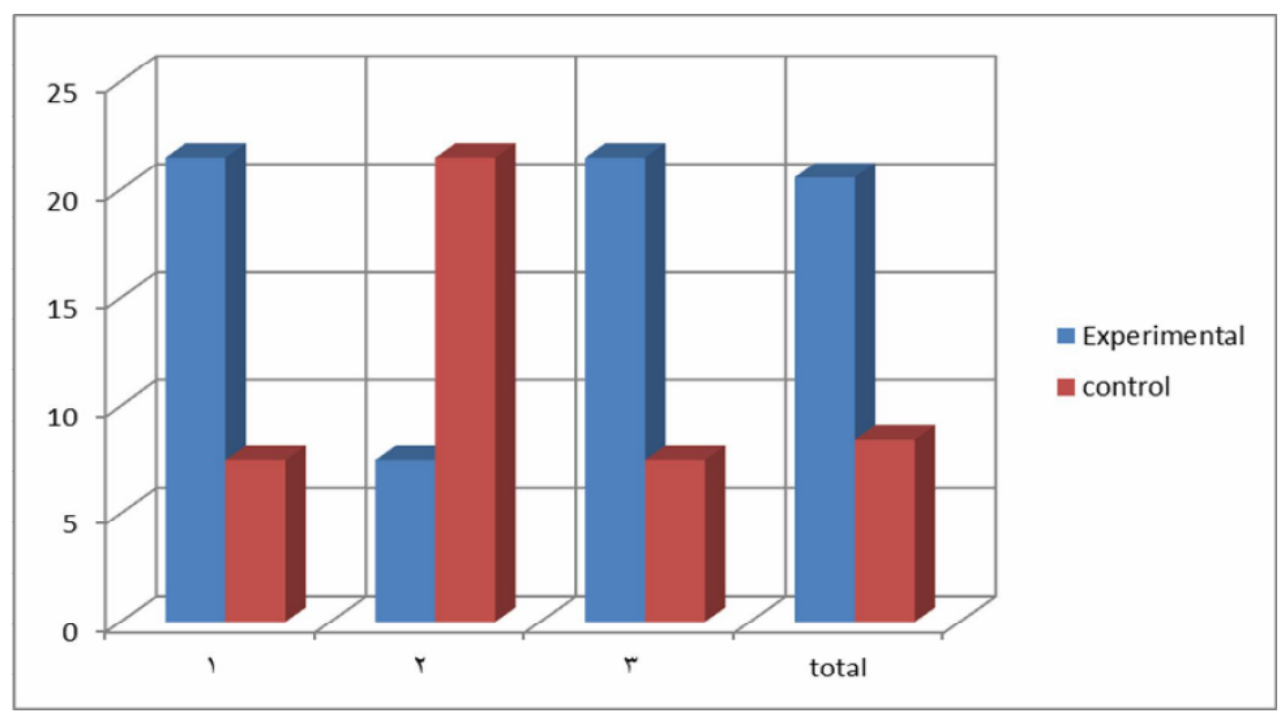

Fig (2): Mean ranks for experimental and control group in motivation post test

The noticeable great turning in the pupils' motivation is surely attributed to the implication of the proposed program which converted the boring exhausting writing class to an enjoyable efficient writing class. 
Working independently on their technical devices motivated the pupils to rise out the closed classroom to an open technical class in which they enjoy and rush to post, share and comment. Consequently, improving the writing skill

Table (3): Establishing the difference in motivation level on pre and post motivation scale of experimental group

\begin{tabular}{|l|l|l|l|l|l|l|}
\hline Dimensions & \multicolumn{2}{l|}{ Mean Rank } & \multicolumn{2}{l|}{ Sum of Ranks } & Z & Sign \\
\hline & $(-)$ & $(+)$ & $(-)$ & $(+)$ & & \\
\hline $\begin{array}{l}\text { attitude toward } \\
\text { enjoying writing }\end{array}$ & 0 & 7.5 & 0 & 105 & 3.304 & 0.01 \\
\hline $\begin{array}{l}\text { challenges while } \\
\text { writing }\end{array}$ & 7.5 & 0 & 105 & 0 & 3.302 & 0.01 \\
\hline $\begin{array}{l}\text { The value of } \\
\text { writing }\end{array}$ & 0 & 7.5 & 0 & 105 & 3.308 & 0.01 \\
\hline Total & 0 & 7.5 & 0 & 105 & 3.299 & 0.01 \\
\hline
\end{tabular}

Table (3) clarifies that the t- value in the total score is significant at 0.05 level. Thus, there is a statistically significant difference between the experimental group pupils' mean score in the pre- and post-administration of the motivation scale in favor of the post administration. The results of the Experimental group pupils' percentages in the writing Motivation scale were significant in favor of the post-administration in most of the scale items.

To sum up, The proposed Edmodo features resulted in enhancing the students' motivation toward writing. This could be attributed to encouraging students to search, share and improve creative ideas, comment on peers' pieces of writing, enrich vocabulary words and independently modify their works. This is consistent with Brozek\& Duckworth(2011) who state that through the use of the discussion board that Edmodo incorporates, students are encouraged not only to collaborate but also to participate in experiential learning as they could express themselves there, even the shyer ones, which can raise motivation. Additionally, Sanders (2012) indicates that Edmodo encourages both student engagement and responsible learning. It allows electronic collaboration through its platform where students' engagement and enjoyment in learning grows, thus making learners motivated as they engage in higher order thinking spurred by online communities. Moreover, Enriquez (2014) finds that the collaboration provided in Edmodo enabled students to improve their online work quality. 
The results prove that there is an obvious improvement in the writing skills and motivation of the experimental group students, as compared to their performance before conducting the experimental treatment. According to this, the hypotheses of the study were proved and accepted

\section{Conclusion}

All in all, the results and the previous studies show the influential Edmodo in the learning environment especially the writing skill. Edmodo has sufficiently turned the monotonous writing class into a lively writing environment run by active and creative pupils.

\section{Recommendations}

In the light of the achieved results, the researcher recommends that schools should take into their accounts the technological revolution and how to implement it effectively in the school. Schools should provide a helpful technical environment with all the resources which qualify both the teacher and the students to go through an effective learning process. Similarly, parents should be aware of all the facilities to help their kids. Identically, it is a sharing task between the school board and the parents at home.

1. Teachers should abandon the traditional methods of the monotonous classical class seeking modern methods for a modern English class.

2. Teachers should update their knowledge technically by joining IT courses to be able to handle any challenges while using the program.

3. Teachers should enrich their knowledge academically and search to supply videos, links, images, and all new age requirements to cope with the students' advanced needs.

4. The school should activate the program to include all the subjects along with the students' portfolios, report cards, notifications, certificates of appreciation.... etc, to enable the students to easily and constantly log in and interact.

\section{References}

Brown, D., \& Warschauer, M. (2006). From the university to the elementary classroom: Students' experiences in learning to integrate technology in instruction. Journal of Technology and Teacher Education, 14(3), 599-621.

Candrasari, M. (2015). The Use of Edmodo Website to Improve Students Writing Skill (Classroom Action Research of the tenth grade students of SMKN 1 Wonosegoro in academic 2015/2016)(Doctoral dissertation, IAIN Salatiga). 
Dörnyei, Z., \& Schmidt, R. (Eds.). (2001). Motivation and second language acquisition (Vol. 23). Natl Foreign Lg Resource Ctr.

Genc Ilter, B. (2009). Effect of technology on motivation in EFL classrooms. Online Submission, 10(4).

Graham, S., \& Perin, D. (2007). Writing next-effective strategies to improve writing of adolescents in middle and high schools.

Hrastinski, S. (2008). What is online learner participation? A literature review. Computers \& Education, 51(4), 1755-1765.

Hyland, F. (2003). Focusing on form: Student engagement with teacher feedback. System, 31(2), 217-230.

Kalanzadeh, G. A., Soleimani, H., \& Bakhtiarvand, M. (2014). Exploring the influence of using technology on Iranian EFL students' motivation. Procedia-Social and Behavioral Sciences, 98, 814-823.

Thien, P. C., Le Van Phan, N. K. L., Tho, Q. T., Suhonen, J., \& Sutinen, E. (2013, November). Applying Edmodo to serve an online distance learning system for undergraduate students in Nong Lam University, Vietnam. In Proceedings of the IETEC'13 Conference. 